\title{
Publisher Correction: Investigating the relationship between Aerosol Optical Depth and Precipitation over Southeast Asia with Relative Humidity as an influencing factor
}

\author{
Daniel Hui Loong Ng${ }^{1,2}$, Ruimin $\mathrm{Li}^{1,2}$, Srivatsan V. Raghavan ${ }^{2,3}$ \& Shie-Yui Liong ${ }^{1,2,3,4}$ \\ Correction to: Scientific Reports https://doi.org/10.1038/s41598-017-10858-1, published online 17 October 2017 \\ In the original HTML version of this Article, Daniel Hui Loong Ng was incorrectly listed as the corresponding \\ author. The correct corresponding author for this Article is Ruimin Li. Correspondence and request for materials \\ should be addressed to: li_ruimin@u.nus.edu
}

This has now been corrected in the HTML version of the paper; the PDF was correct from the time of publication.

(c) (i) Open Access This article is licensed under a Creative Commons Attribution 4.0 International License, which permits use, sharing, adaptation, distribution and reproduction in any medium or format, as long as you give appropriate credit to the original author(s) and the source, provide a link to the Creative Commons license, and indicate if changes were made. The images or other third party material in this article are included in the article's Creative Commons license, unless indicated otherwise in a credit line to the material. If material is not included in the article's Creative Commons license and your intended use is not permitted by statutory regulation or exceeds the permitted use, you will need to obtain permission directly from the copyright holder. To view a copy of this license, visit http://creativecommons.org/licenses/by/4.0/.

(c) The Author(s) 2018

\footnotetext{
${ }^{1}$ Department of Civil and Environmental Engineering, National University of Singapore, Singapore, Singapore. ${ }^{2}$ Tropical Marine Science Institute, National University of Singapore, Singapore, Singapore. ${ }^{3}$ Center for Environmental Sensing and Modeling, Singapore-MIT Alliance for Research and Technology, Singapore, Singapore. ${ }^{4}$ Willis Re Inc., London, UK. Correspondence and requests for materials should be addressed to R.L. (email: li_ruimin@u.nus.edu)
} 